\title{
Genetic Diversity Analysis of Table Potato Genotypes Using SSR Markers
}

\author{
B. R. S. S. Singh ${ }^{1 *}$, A. Mishra ${ }^{1}$, M. K. Kar ${ }^{2}$, R. P. Sah ${ }^{2}$, M. Behera ${ }^{2}$ and A. Bal ${ }^{2}$ \\ ${ }^{1}$ All India Coordinated Research Project on Potato, Odisha University of Agriculture \& \\ Technology, Bhubaneswar, Odisha, India \\ ${ }^{2}$ ICAR-National Rice Research Institute, Cuttack, Odisha, India \\ *Corresponding author
}

\section{A B S T R A C T}

\begin{tabular}{|l|}
\hline Ke y w o r d s \\
Table potato, \\
Diversity, \\
Morphological \\
characters, \\
UPGMA, SSR \\
markers \\
\hline Article Info \\
\hline $\begin{array}{l}\text { Accepted: } \\
\text { 24 July 2020 } \\
\text { Available Online: } \\
\text { 10 August } 2020\end{array}$ \\
\hline
\end{tabular}

An experiment was carried out at AICRP on Potato under Odisha University of Agriculture and Technology, Bhubaneswar to study diversity among morphologically distinguishable potato genotypes with SSR markers. Twenty potato genotypes were laid out in a Randomized Block Design with four replications. Eight morphological characters were observed based on DUS characteristics to visually differentiate genotypes. In addition, fifteen SSR markers were used to depict clear-cut variation among genotypes with the aid of polymorphic bands. A total of 51 loci were amplified by 15 SSR markers which exhibited 92.16 percent polymorphism. The PIC values varied widely among 15 SSR loci tested and ranged from a minimum 0.2078 (STM1106) to maximum 0.7756 (STM0019) with an average of 0.5200 . Heterozygosity values ranged from minimum 0.2659 (STM1106) to maximum 0.8047 (STM0019). The Jaccard's dissimilarity coefficient was found to vary from 0.321 to 0.628 . The binary data were used to calculate genetic dissimilarities based on Jaccard's coefficient and UPGMA (Unweighted Pair Group Method using Arithmetical Means). A dendrogram was constructed using DARwin version 6 software, exhibiting pictorial expression of diverse genotypes. UPGMA divided the populations of 20 genotypes into six clusters; Cluster IV being the largest containing seven genotypes. Kufri Lima was found to be the most divergent from rest of the genotypes.

\section{Introduction}

Potato (Solanum tuberosum L.), an annual vegetable crop, belongs to Solanaceae family. It is grown widely in the world and provides high yield even under variable soil and weather conditions (Lisinska and Leszcynski, 1989). This starchy edible tuber has high consumption rate due to its palatability and rich nutritive value (Rytel et al., 2005).
Potatoes serve as a major food source, as well as an inexpensive source of energy and good quality protein (Lachman et al., 2001). In India, improved varieties of this species released from ICAR-Central Potato Research Institute, Shimla are the most widely cultivated although few old varieties like Phulwa, Darjeeling Red Round and Gola are still popular at certain locations. 
Being a polyploid with clonal propagation, genetic diversity plays a very crucial role in potato breeding because heterozygosity is conserved during asexual propagation and hybrids between lines of diverse genetics display greater heterosis and segregants than the closely related parents. Thus, selection of parental material to be used for a particular mating design is important in breeding potato like other polyploid crops. A number of approaches have been used by plant breeders to select the best parents and crosscombinations. These include: combining ability, use of mid-parent values, progeny tests, estimated breeding values, and genetic diversity (Gopal, 2015). Assessment of diversity can be done through the use of phenotypic information, pedigree, biochemical and molecular markers (Govindaraj et al., 2015). The use of molecular markers is limited in this crop although it can be a most reliable method for assessing genetic diversity. Molecular markers are stable and not dependent on environment or developmental stage of the plant. Different molecular markers have been used to estimate genetic diversity in crop plants.

Microsatellites are highly polymorphic, abundant, co-dominant and can be used to detect heterozygosity. SSR (simple sequence repeats) have a higher rate of mutation than other areas of DNA leading to high genetic diversity. SSR, being co-dominant markers, allows all the alleles except null ones to be observed at each locus using acrylamide gel electrophoresis or sequencing systems.

In the present study, random SSR markers were selected based on their PIC values and annealing temperature and used foridentification of polymorphic markers, assessing the genetic diversity among potato genotypes under study and pictorial representation of different clusters using dendrogram.

\section{Materials and Methods}

\section{Plant material and agronomic management}

The test entries comprised of twenty potato genotypes including 13 released cultivars and seven promising cultures evaluated and maintained at All India Coordinated Research Project on Potato, Odisha University of Agriculture \& Technology, Bhubaneswar, Odisha. The source of genotypes is presented in Table 1. During investigation, eight morphological characters were observed viz. stem colour, stem cross-section, leaf structure, leaflet shape, tuber shape, tuber skin colour, tuber eyes and tuber flesh colour. The data were recorded as per methods adopted in DUS testing (PPV \& FR Act, 2001.). Recommended agricultural practices were followed to raise the crop.

\section{Morphological characters}

Thecolour of the stem was observed visually and recorded as green, reddish-brown or purple (Table 2). Similarly, the stem cross section was recorded as round and angular; the leaf structure as open, intermediate or close; the leaflet shape as lanceolate, ovate lanceolate, ovate or oval; the shape of tuber as round, ovoid, oblong; the skin colour of the tuber as whitish cream, yellow or red; the eyes of tubers as shallow, medium-deep or deep; and the flesh colour of tuber as white, cream or yellow.

\section{DNA extraction and SSR amplification}

\section{Sample preparation}

At the crop age of 20-30 days, fresh and green leaves were collected from young plants of each genotype. The leaves of $2 \times 2 \mathrm{~cm}$ size were taken and washed with double distilled water to remove the dust particles. The leaf discs were kept in airtight $25 \mathrm{ml}$ plastic tube 
and placed in ice box. After reaching to laboratory, these were wiped with $70 \%$ ethanol to remove other contaminants. The leaf material was further sealed in polythene bags and stored at a temperature of $-80^{\circ} \mathrm{C}$.

\section{Isolation of genomic DNA by Sodium Dodecyl Sulfate (SDS) method}

Leaf sample was ground using liquid nitrogen. Then, SDS buffer $(600 \mu \mathrm{l})$ was added and mixed well. The tubes were kept in water bath at $65^{\circ} \mathrm{C}$ for 10 minutes. $300 \mu \mathrm{l}$ of $3 \mathrm{M}$ sodium acetate was added to each tube and incubated at $-20^{\circ} \mathrm{C}$ for 1 hour. The sample was then centrifuged $(13000 \mathrm{rpm})$ at $25^{\circ} \mathrm{C}$ for 10 minutes. The supernatant was transferred to fresh tubes and $500 \mu \mathrm{l}$ of chilled isopropanol was added. The tubes were incubated overnight at $-20^{\circ} \mathrm{C}$. The sample was again centrifuged $(13000 \mathrm{rpm})$ at $4^{\circ} \mathrm{C}$ for 10 minutes. The supernatant was discarded and the tubes were washed with $70 \%$ ethanol. Ethanol was discarded and the tubes were allowed to dry for 1 hour. After drying, the tubes containing DNA pellets were incubated at $37^{\circ} \mathrm{C}$ for 1 hour. The DNA pellets were dissolved in TE buffer $(0.1 \mathrm{x})$ and stored at $20^{\circ} \mathrm{C}$.

\section{PCR program}

a) Initial denaturation at $94{ }^{\circ} \mathrm{C}$ for $5 \mathrm{~min}$

b) 35 cycles: Denaturation at $94{ }^{\circ} \mathrm{C}$ for 30 seconds

Annealing at $55^{\circ} \mathrm{C}$ for 45 seconds

Extension at $72^{\circ} \mathrm{C}$ for 1 minute

c) Final extension at $72^{\circ} \mathrm{C}$ for 10 minutes.

\section{Procedure for gel electrophoresis}

Agarose gel (2.5\%) was prepared and 0.5 $\mu \mathrm{g} / \mathrm{ml}$ of ethidium bromide was added. The warm agarose solution was poured into the gel casting tray and allowed to set completely. The gel caster was placed in an electrophoretic chamber (It is important to use the same batch of electrophoresis buffer in both the electrophoresis tank and the gel preparation). Enough electrophoresis buffer was added to cover the gel to a depth of approximately $2 \mathrm{~mm}$. The samples of PCR amplified DNA were mixed with desired gelloading dye. The sample mixtures were slowly loaded into the slots of the submerged gel using a disposable micropipette. Load size standards (ladders) into a slot on the left side of the gel. The electrical leads were connected so that the DNA will migrate towards the positive anode (red lead). A voltage of 1-5 V/cm was applied (measured as the distance between the positive and negative electrodes). If the leads have been attached correctly, bubbles should be generated at the anode and cathode. The gel was run until the bromophenol blue has migrated an appropriate distance through the gel (the presence of ethidium bromide allows the gel to be examined by UV illumination at any stage during electrophoresis). The gel was removed from the electrophoretic chamber and placed directly on a transilluminator.

\section{Data analysis}

Only the clear and unambiguous bands of SSR markers were scored. The sizes of the amplified fragments were estimated with the help of Alpha image software by Gel documentation system using $50 \mathrm{bp}$ or $100 \mathrm{bp}$ DNA ladders as size standards. Markers were scored for the presence or absence of the corresponding allele among the genotypes. The score ' 1 ' and ' 0 ' indicates the presence and absence of the bands, respectively. The binary data were used to calculate genetic dissimilarities based on Jaccard's coefficient (Jaccard, 1901) and UPGMA (Unweighted Pair Group Method with Arithmetic Mean). Dendrogram was generated to determine the genetic relationship of potato genotypes. DNA marker polymorphism rates could be 
determined using polymorphism information content (PIC) value. Darwin 6 and Microsoft Excel were used for data analysis.

\section{Marker polymorphism}

Fifteen SSR markers were utilized in the present study (Table 3 ). The polymorphism information content (PIC) for each SSR marker was calculated according to the formula (Botstein et al., 1980).

$$
\mathrm{PIC}=1-\left(\sum_{\mathrm{i}=1}^{\mathrm{n}} \mathrm{Pi}^{2}\right)-\sum_{\mathrm{i}=1}^{\mathrm{n}-1} \sum_{\mathrm{j}=\mathrm{i}+1}^{\mathrm{n}} 2 \mathrm{Pi}^{2} \mathrm{Pj}^{2}
$$

Where ' $i$ ' is the total number of alleles detected for SSR marker and ' $\mathrm{Pi}$ ' is the frequency of the $i^{\text {th }}$ allele in the set of 20 genotypes investigated and $\mathrm{j}=\mathrm{i}+1$. This formula gives us an indicator of how many alleles a certain marker has and how many of these alleles divide evenly.

\section{Results and Discussion}

\section{Variation in morphological characters}

The genotypes were phenotyped for eight important DUS traits (Table 2). The colour of the stem was observed visually and recorded as green, red-brown and purple. Among all the genotypes, 85 percent genotypes showed green stem colour. The stem cross section was found to be round and angular. Among all the genotypes, 70 percent genotypes showed round cross-section.

The leaf structure was found to be open, intermediate and close. Among all the genotypes, 60 percent genotypes showed intermediate leaf structure.

The leaflet shape was found to belanceolate, ovate lanceolate, ovate and oval. Among all the genotypes, 45 percent genotypes showed ovate lanceolate shape.
The shape of tuber was found to be round, ovoid, oblong. Among all the genotypes, 55 percent genotypes showed ovoid shape.

The skin colour of the tuber was found to be whitish cream, yellow and red. Among all the genotypes, 50 percent genotypes showed whitish cream tuber colour.

The eyes of tubers were found to be shallow, medium-deep and deep. Among all the genotypes, 50 percent genotypes showed medium-deep tuber eyes.

The flesh colour of tuber was found to be white, cream and yellow. Among all the genotypes, 45 percent genotypes showed cream tuber flesh colour.

\section{Allelic information}

All the markers detected more than one locus with an average of 3.4 loci per marker and were observed to be polymorphic; thus enabled grouping different genotypes. A total of 51 loci were observed using 15 SSR markers. Out of 51 loci, the number of polymorphic loci were $47(92.16 \%)$ and the remaining 4 loci of each marker viz., S189 (195 bp), STI0030 (90 bp), STG0016 (150 bp) and S192 (175 bp) were monomorphic (Fig. 1). Thus, these highly polymorphic markers are sufficient to capture the genotypic variation in these potato genotypes. The number of polymorphic loci ranged from 1 to 6 with an average of 3.13. The overall size of the amplified product varied from 80 bp (marker STM0037) to 250 bp (marker STM0019).

Polymorphism information content (PIC) value is the reflection of allele diversity and their frequency among genotypes. In the present study, the PIC values varied widely among 15 SSR loci tested and ranged from 0.2078 (STM1106) to 0.7756 (STM0019) 
with an average of 0.5200 . DNA markers showed an average PIC value of $>0.5$, which confirms that markers are highly informative (Botstein et al., 1980).High level of allelic diversity (4-35 alleles per SSR locus) with high PIC values (0.53-0.92) having 1492 absolute frequencies using 12 SSR markers are an indicative of allelic richness in Indian potato varieties (Jageshet al., 2018). SSR revealed higher frequency of polymorphic bands (93.1\%) than RAPD (57.4\%) (Mahmoud et al., 2012).

Heterozygosity values $(\mathrm{He})$, the measure of allelic diversity at a locus, ranged from 0.2659 (STM1106) to 0.8047 (STM0019). Prossy et al., (2017) found that heterozygosity values $(\mathrm{He})$ ranged from 0.099 to 0.805 with an average of 0.467 .

\section{Cluster analysis of potato clones}

UPGMA divided the populations of 20 genotypes into six clusters. The dendrogram was constructed using Jaccard's dissimilarity matrix of SSR markers involving data generated out of fifteen primers on twenty genotypes of potato (Fig. 2).

Based on the SSR marker data, the Jaccard's dissimilarity coefficients were estimated between pair of genotypes (Table 4). The dissimilarity coefficient was found to vary from 0.321 to 0.628 . The lowest value for genetic dissimilarity (0.321) was found between genotypes AICRP P-12 and AICRP $\mathrm{P}-31$; it means that they are most similar. $\mathrm{K}$ Lima was found to be most divergent from rest of the genotypes.

Cluster I consisted of four genotypes namely AICRP P-7, K Lalima, K Pushkar and K Pukhraj. It can be sub divided into two sub clusters; Subcluster- A (AICRP P-7, K
Lalima) and Subcluster-B (K Pushkar, K Pukhraj) containing two genotypes each.

Cluster II consisted of two genotypes namely AICRP P-29 and K Jyoti.

Cluster III consisted of four genotypes namely K Surya, K Ashoka, AICRP P-22 and AICRP P-36. It can be divided into two sub clusters, such as Subcluster-C (K Surya, K AShoka) and Subcluster-D (AICRP P-22, AICRP P-36) containing two genotypes each.

Cluster IV was the largest containing seven genotypes namely $\mathrm{K}$ Chipsona-3, AICRP P24, K Lalit, AICRP P-31, AICRP P-12, K Ganga and $\mathrm{K}$ Mohan. It can be sub divided into four sub clusters viz. Subcluster-E (K Chipsona-3, AICRP P-24), Subcluster-F (K Lalit), Subcluster-G (AICRP P-31, AICRP P12 and $\mathrm{K}$ Ganga) and Subcluster-H (K Mohan).

Cluster V consisted of two genotypes namely K Khyati and K Chipsona-1.

Cluster VI was the smallest containing only one genotype K Lima.

SSRs are codominant markers and give reproducible results because they are mostly developed from introns. They are said to be highly specific and especially useful for mapping in tetraploid potato. Milbourne et al.,(1997) compared different types of PCR derived markers to estimate variability and concluded that SSRs offer an effective means of analyzing genetic distance between potato genotypes. In our study, SSRs produced specific patterns, high polymorphism and placed genotypes in 6 clusters. Similar findings were recorded by Ghislain et al., (2006) and Moisan Thiery et al., (2005). 
Table.1 Source of potato genotypes under study

\begin{tabular}{|l|l|l|}
\hline SI. No. & Genotypes & Source \\
\hline $\mathbf{1}$ & AICRP-P-7 & CPRI RS, Modipuram \\
\hline $\mathbf{2}$ & AICRP-P-12 & CPRI RS, Modipuram \\
\hline $\mathbf{3}$ & AICRP-P-24 & CPRI RS, Modipuram \\
\hline $\mathbf{4}$ & AICRP-P-22 & CPRI RS, Modipuram \\
\hline $\mathbf{5}$ & Kufri Ganga & CPRI RS,Modipuram \\
\hline $\mathbf{6}$ & KufriKhyati & CPRI RS, Modipuram \\
\hline $\mathbf{7}$ & KufriPukhraj & CPRI RS, Modipuram \\
\hline $\mathbf{8}$ & KufriAshoka & CPRS, Patna \\
\hline $\mathbf{9}$ & KufriJyoti & CPRS, Jalandhar \\
\hline $\mathbf{1 0}$ & KufriLalima & CPRI RS, Modipuram \\
\hline $\mathbf{1 1}$ & Kufri -Chipsona-3 & CPRI RS, Modipuram \\
\hline $\mathbf{1 2}$ & Kufri Mohan & CPRI RS, Modipuram \\
\hline $\mathbf{1 3}$ & KufriLalit & CPRI RS, Modipuram \\
\hline $\mathbf{1 4}$ & Kufri -Chipsona-1 & CPRI RS, Modipuram \\
\hline $\mathbf{1 5}$ & AICRP-P-29 & CPRI RS, Modipuram \\
\hline $\mathbf{1 6}$ & AICRP-P-31 & CPRI RS, Modipuram \\
\hline $\mathbf{1 7}$ & AICRP-P-36 & CPRI RS, Modipuram \\
\hline $\mathbf{1 8}$ & KufriPushkar & CPRI RS, Modipuram \\
\hline $\mathbf{1 9}$ & Kufri Lima & CPRI RS, Modipuram \\
\hline $\mathbf{2 0}$ & Kufri Surya & CPRI RS, Modipuram \\
\hline & & \\
\hline
\end{tabular}


Table.2 Morphological characters of 20 potato (Solanum tuberosum L.) genotypes

\begin{tabular}{|c|c|c|c|c|c|c|c|c|}
\hline \multirow[t]{2}{*}{ Genotypes } & \multicolumn{2}{|c|}{ Stem } & \multicolumn{2}{|c|}{ Foliage } & \multicolumn{4}{|c|}{ Tuber } \\
\hline & Colour & $\begin{array}{l}\text { Cross- } \\
\text { section }\end{array}$ & $\begin{array}{c}\text { Leaf } \\
\text { structure }\end{array}$ & $\begin{array}{c}\text { Leaflet } \\
\text { shape }\end{array}$ & Shape & $\begin{array}{l}\text { Skin } \\
\text { colour }\end{array}$ & Eyes & $\begin{array}{l}\text { Flesh } \\
\text { colour }\end{array}$ \\
\hline AICRP-P-7 & Green & Round & Intermediate & Lanceolate & Round & Red & Deep & Yellow \\
\hline AICRP-P-12 & Green & Round & Close & Ovate & Round & Red & Deep & White \\
\hline AICRP-P-24 & Green & Round & Close & Ovate & Ovoid & $\begin{array}{l}\text { Whitish } \\
\text { cream }\end{array}$ & Shallow & White \\
\hline AICRP-P-22 & Green & Round & Intermediate & Ovate & Oblong & $\begin{array}{l}\text { Whitish } \\
\text { cream }\end{array}$ & Shallow & Yellow \\
\hline K Ganga & Green & Round & Close & Ovate & Round & $\begin{array}{l}\text { Whitish } \\
\text { cream }\end{array}$ & $\begin{array}{c}\text { Medium } \\
\text { deep }\end{array}$ & Cream \\
\hline K Khyati & Green & Angular & Open & $\begin{array}{c}\text { Ovate } \\
\text { lanceolate }\end{array}$ & Ovoid & $\begin{array}{l}\text { Whitish } \\
\text { cream }\end{array}$ & $\begin{array}{l}\text { Medium } \\
\text { deep }\end{array}$ & Cream \\
\hline K Pukhraj & Purple & Angular & Intermediate & $\begin{array}{c}\text { Ovate } \\
\text { lanceolate }\end{array}$ & Ovoid & Yellow & Shallow & Yellow \\
\hline K Ashoka & Green & Round & Intermediate & $\begin{array}{c}\text { Ovate } \\
\text { lanceolate }\end{array}$ & Ovoid & $\begin{array}{l}\text { Whitish } \\
\text { cream }\end{array}$ & $\begin{array}{c}\text { Medium } \\
\text { deep }\end{array}$ & White \\
\hline K Jyoti & $\begin{array}{l}\text { Red- } \\
\text { brown }\end{array}$ & Round & Close & Ovate & Ovoid & $\begin{array}{l}\text { Whitish } \\
\text { cream }\end{array}$ & Shallow & Cream \\
\hline K Lalima & Purple & Round & Intermediate & $\begin{array}{c}\text { Ovate } \\
\text { lanceolate }\end{array}$ & Round & Red & Deep & White \\
\hline K Chipsona-3 & Green & Round & Intermediate & $\begin{array}{c}\text { Ovate } \\
\text { lanceolate }\end{array}$ & Ovoid & $\begin{array}{l}\text { Whitish } \\
\text { cream }\end{array}$ & Shallow & Cream \\
\hline K Mohan & Green & Angular & Open & Ovate & Ovoid & Yellow & $\begin{array}{l}\text { Medium } \\
\text { deep }\end{array}$ & White \\
\hline K Lalit & Green & Angular & Intermediate & Ovate & Round & Red & $\begin{array}{c}\text { Medium } \\
\text { deep }\end{array}$ & Yellow \\
\hline K Chipsona-1 & Green & Round & Intermediate & $\begin{array}{c}\text { Ovate } \\
\text { lanceolate }\end{array}$ & Ovoid & $\begin{array}{l}\text { Whitish } \\
\text { cream }\end{array}$ & -Shallow & Cream \\
\hline AICRP-P-29 & Green & Angular & Intermediate & Oval & Ovoid & Yellow & $\begin{array}{c}\text { Medium } \\
\text { deep }\end{array}$ & Cream \\
\hline AICRP-P-31 & Green & Angular & Close & $\begin{array}{c}\text { Ovate } \\
\text { lanceolate }\end{array}$ & Ovoid & $\begin{array}{l}\text { Whitish } \\
\text { cream }\end{array}$ & Mediumdeep & White \\
\hline AICRP-P-36 & Green & Round & Intermediate & Lanceolate & Round & $\begin{array}{l}\text { Whitish } \\
\text { cream }\end{array}$ & Mediumdeep & Cream \\
\hline K Pushkar & Green & Round & Open & $\begin{array}{c}\text { Ovate } \\
\text { lanceolate }\end{array}$ & Ovoid & Yellow & Mediumdeep & Cream \\
\hline K Lima & Green & Round & Intermediate & Oval & Round & Yellow & Mediumdeep & White \\
\hline K Surya & Green & Round & Intermediate & $\begin{array}{c}\text { Ovate } \\
\text { lanceolate }\end{array}$ & Oblong & Yellow & Shallow & Cream \\
\hline
\end{tabular}


Table.3 Primers used for mole cular diversity analysis

\begin{tabular}{|c|c|c|c|c|c|c|c|}
\hline $\begin{array}{l}\text { SI } \\
\text { no }\end{array}$ & $\begin{array}{c}\text { Primer } \\
\text { name }\end{array}$ & $\begin{array}{l}\text { Primer sequences }\left(5^{6}-3^{\circ}\right) \text { Forward- } \\
\text { Reverse }\end{array}$ & $\begin{array}{l}\text { Annealing } \\
\text { temp }\left({ }^{\circ} \mathrm{C}\right)\end{array}$ & PIC & $\begin{array}{l}\text { Heterozy } \\
\text { gosity }\end{array}$ & $\begin{array}{l}\text { No. of } \\
\text { alleles }\end{array}$ & $\begin{array}{c}\text { No. of } \\
\text { PL }\end{array}$ \\
\hline 1 & STI031 & $\begin{array}{l}\text { CAGAGGATGCTGATGGACCT } \\
\text { GGAGCAGTTGAGGGCTTCTT }\end{array}$ & 57 & 0.5254 & 0.6055 & 4 & 4 \\
\hline 2 & STI046 & $\begin{array}{l}\text { CAGAGGATGCTGATGGACCT } \\
\text { GGAGCAGTTGAGGGCTTCTT }\end{array}$ & 57 & 0.5439 & 0.6152 & 4 & 4 \\
\hline 3 & S189 & $\begin{array}{l}\text { CCTTGTAGAACAGCAGTGGTC } \\
\text { TCCGCCAAGACTGATGCA }\end{array}$ & 55 & 0.6343 & 0.6836 & 4 & 3 \\
\hline 4 & S153 & $\begin{array}{l}\text { TATGTTCCACGCCATTTCAG } \\
\text { ACGGAAACTCATCGTGCATT }\end{array}$ & 55 & 0.6295 & 0.6869 & 4 & 4 \\
\hline 5 & STM0037 & $\begin{array}{l}\text { AATTTAACTTAGAAGATTAGT } \\
\text { CTCATTTGGTTGGGTATGATA }\end{array}$ & 55 & 0.5363 & 0.6139 & 3 & 3 \\
\hline 6 & STM1052 & $\begin{array}{l}\text { CAATTTCGTTTTTTCATGTGAC } \\
\text { ACATGGCGTAATTTGATTTAA } \\
\text { TACGTAA }\end{array}$ & 55 & 0.5739 & 0.6493 & 3 & 3 \\
\hline 7 & STI0030 & $\begin{array}{l}\text { TTGACCCTCCAACTATAGATT } \\
\text { CTTCTGACAACTTTAAAGCAT } \\
\text { ATGTCAGC }\end{array}$ & 56 & 0.3457 & 0.4444 & 2 & 1 \\
\hline 8 & STM0019 & $\begin{array}{l}\text { AATAGGTGTACTGACTCTCAA } \\
\text { TGTTGAAGTAAAAGTCCTAGT } \\
\text { ATGTG }\end{array}$ & 47 & 0.7756 & 0.8047 & 6 & 6 \\
\hline 9 & STI24 & $\begin{array}{l}\text { CGCCATTCTCTCAGATCACTC } \\
\text { GCTGCAGCAGTTGTTGTTGT }\end{array}$ & 60 & 0.6844 & 0.7337 & 4 & 4 \\
\hline 10 & STI57 & $\begin{array}{l}\text { CCTTGTAGAACAGCAGTGGTC } \\
\text { TCCGCCAAGACTGATGCA }\end{array}$ & 60 & 0.5169 & 0.595 & 3 & 3 \\
\hline 11 & STG0016 & $\begin{array}{l}\text { AGCTGCTCAGCATCAAGAGA } \\
\text { ACCACCTCAGGCACTTCATC }\end{array}$ & 56 & 0.445 & 0.4978 & 3 & 2 \\
\hline 12 & STM1106 & $\begin{array}{l}\text { TCCAGCTGATTGGTTAGGTTG } \\
\text { ATGCGAATCTACTCGTCATGG }\end{array}$ & 57 & 0.2078 & 0.2659 & 2 & 2 \\
\hline 13 & S182 & $\begin{array}{l}\text { GGAAGTCCTCAACTGGCTG } \\
\text { TCAACTATATGCCTACTGCCC } \\
\text { AA }\end{array}$ & 55 & 0.6443 & 0.7012 & 4 & 4 \\
\hline 14 & S192 & $\begin{array}{l}\text { ACTTCTGCATCTGGTGAAGC } \\
\text { GGTCTGGATTCCCAGGTTG }\end{array}$ & 55 & 0.2392 & 0.2778 & 2 & 1 \\
\hline 15 & STI0032 & $\begin{array}{l}\text { TGGGAAGAATCCTGAAATGG } \\
\text { TGCTCTACCAATTAACGGCA }\end{array}$ & 60 & 0.4992 & 0.56 & 3 & 3 \\
\hline
\end{tabular}

PIC-Polymorphism information content, PL-polymorphic loci. 
Table.4 Pair wise dissimilarity matrix based on Jaccard's coefficient of SSR for all 20 potato genotypes

\begin{tabular}{|c|c|c|c|c|c|c|c|c|c|c|c|c|c|c|c|c|c|c|c|}
\hline Genotypes & 1 & 2 & 3 & 4 & 5 & 6 & 7 & 8 & 9 & 10 & 11 & 12 & 13 & 14 & 15 & 16 & 17 & 18 & 19 \\
\hline 2 & 0.469 & & & & & & & & & & & & & & & & & & \\
\hline 3 & 0.616 & 0.616 & & & & & & & & & & & & & & & & & \\
\hline 4 & 0.616 & 0.616 & 0.574 & & & & & & & & & & & & & & & & \\
\hline 5 & 0.616 & 0.616 & 0.574 & 0.538 & & & & & & & & & & & & & & & \\
\hline 6 & 0.616 & 0.616 & 0.394 & 0.574 & 0.574 & & & & & & & & & & & & & & \\
\hline 7 & 0.616 & 0.616 & 0.574 & 0.345 & 0.538 & 0.574 & & & & & & & & & & & & & \\
\hline 8 & 0.616 & 0.616 & 0.585 & 0.585 & 0.585 & 0.585 & 0.585 & & & & & & & & & & & & \\
\hline 9 & 0.616 & 0.616 & 0.574 & 0.538 & 0.459 & 0.574 & 0.538 & 0.585 & & & & & & & & & & & \\
\hline 10 & 0.628 & 0.628 & 0.628 & 0.628 & 0.628 & 0.628 & 0.628 & 0.628 & 0.628 & & & & & & & & & & \\
\hline 11 & 0.616 & 0.616 & 0.574 & 0.538 & 0.400 & 0.574 & 0.538 & 0.585 & 0.459 & 0.628 & & & & & & & & & \\
\hline 12 & 0.616 & 0.616 & 0.585 & 0.585 & 0.585 & 0.585 & 0.585 & 0.499 & 0.585 & 0.628 & 0.585 & & & & & & & & \\
\hline 13 & 0.616 & 0.616 & 0.574 & 0.538 & 0.459 & 0.574 & 0.538 & 0.585 & 0.357 & 0.628 & 0.459 & 0.585 & & & & & & & \\
\hline 14 & 0.616 & 0.616 & 0.585 & 0.585 & 0.585 & 0.585 & 0.585 & 0.539 & 0.585 & 0.628 & 0.585 & 0.539 & 0.585 & & & & & & \\
\hline 15 & 0.616 & 0.616 & 0.585 & 0.585 & 0.585 & 0.585 & 0.585 & 0.374 & 0.585 & 0.628 & 0.585 & 0.499 & 0.585 & 0.539 & & & & & \\
\hline 16 & 0.616 & 0.616 & 0.585 & 0.585 & 0.585 & 0.585 & 0.585 & 0.374 & 0.585 & 0.628 & 0.585 & 0.499 & 0.585 & 0.539 & 0.321 & & & & \\
\hline 17 & 0.616 & 0.616 & 0.497 & 0.574 & 0.574 & 0.497 & 0.574 & 0.585 & 0.574 & 0.628 & 0.574 & 0.585 & 0.574 & 0.585 & 0.585 & 0.585 & & & \\
\hline 18 & 0.616 & 0.616 & 0.585 & 0.585 & 0.585 & 0.585 & 0.585 & 0.499 & 0.585 & 0.628 & 0.585 & 0.474 & 0.585 & 0.539 & 0.499 & 0.499 & 0.585 & & \\
\hline 19 & 0.616 & 0.616 & 0.497 & 0.574 & 0.574 & 0.497 & 0.574 & 0.585 & 0.574 & 0.628 & 0.574 & 0.585 & 0.574 & 0.585 & 0.585 & 0.585 & 0.407 & 0.585 & \\
\hline 20 & 0.616 & 0.616 & 0.585 & 0.585 & 0.585 & 0.585 & 0.585 & 0.499 & 0.585 & 0.628 & 0.585 & 0.440 & 0.585 & 0.539 & 0.499 & 0.499 & 0.585 & 0.474 & 0.585 \\
\hline
\end{tabular}

1-K Chipsona-1, 2-K Khyati, 3-AICRP-P-36, 4-K Jyoti, 5- K Lalima, 6- AICRP-P-22, 7- AICRP-P-29, 8- K Ganga, 9- K Pukhraj, 10- K Lima, 11- AICRP-P-7, 12- AICRP-P-24, 13- K Pushkar, 14- K Mohan, 15- AICRP-P-12, 16- AICRP-P-31, 17- K Ashoka, 18- K Lalit, 19- K Surya, 20- K Chipsona-3. 


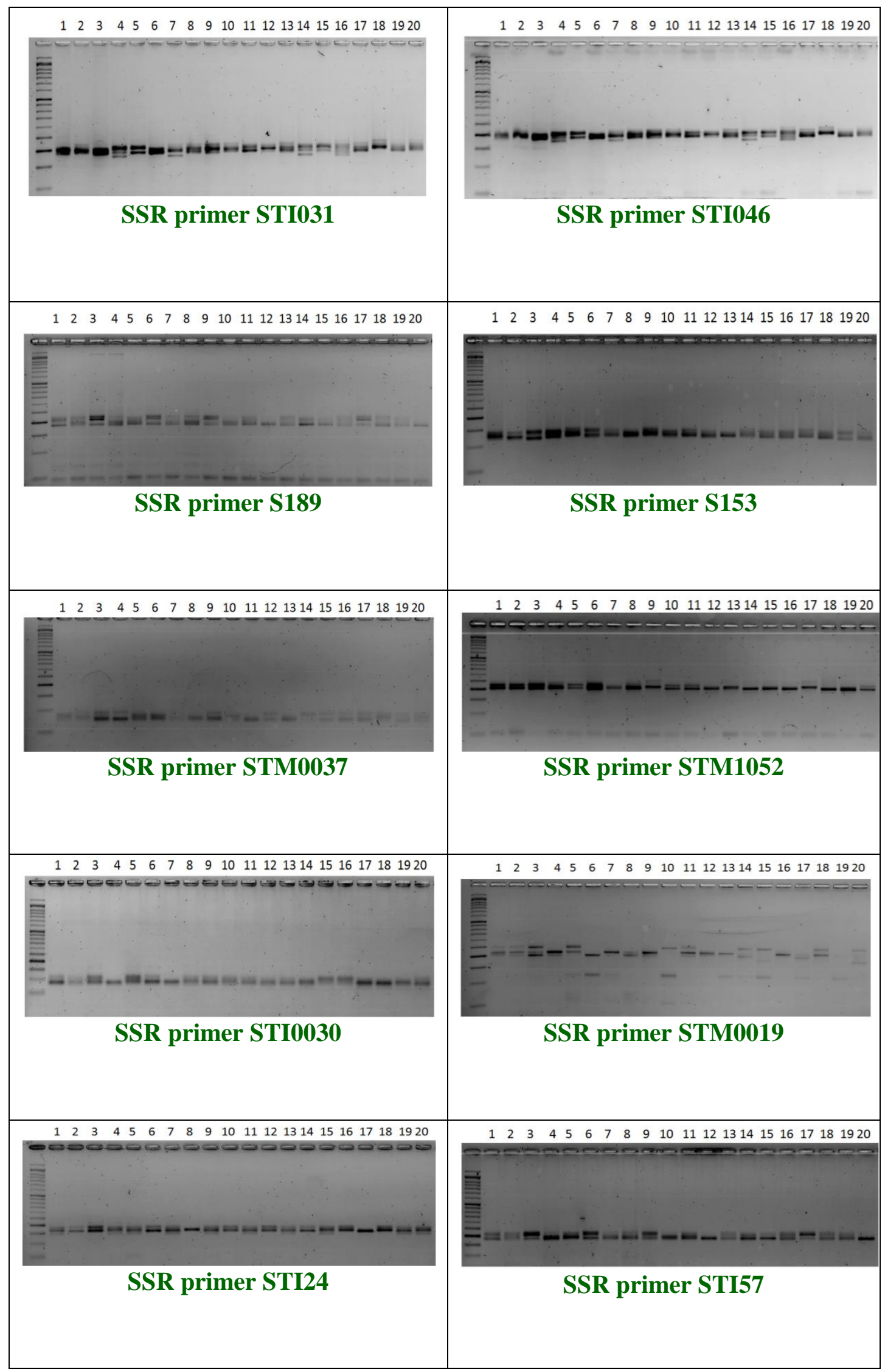




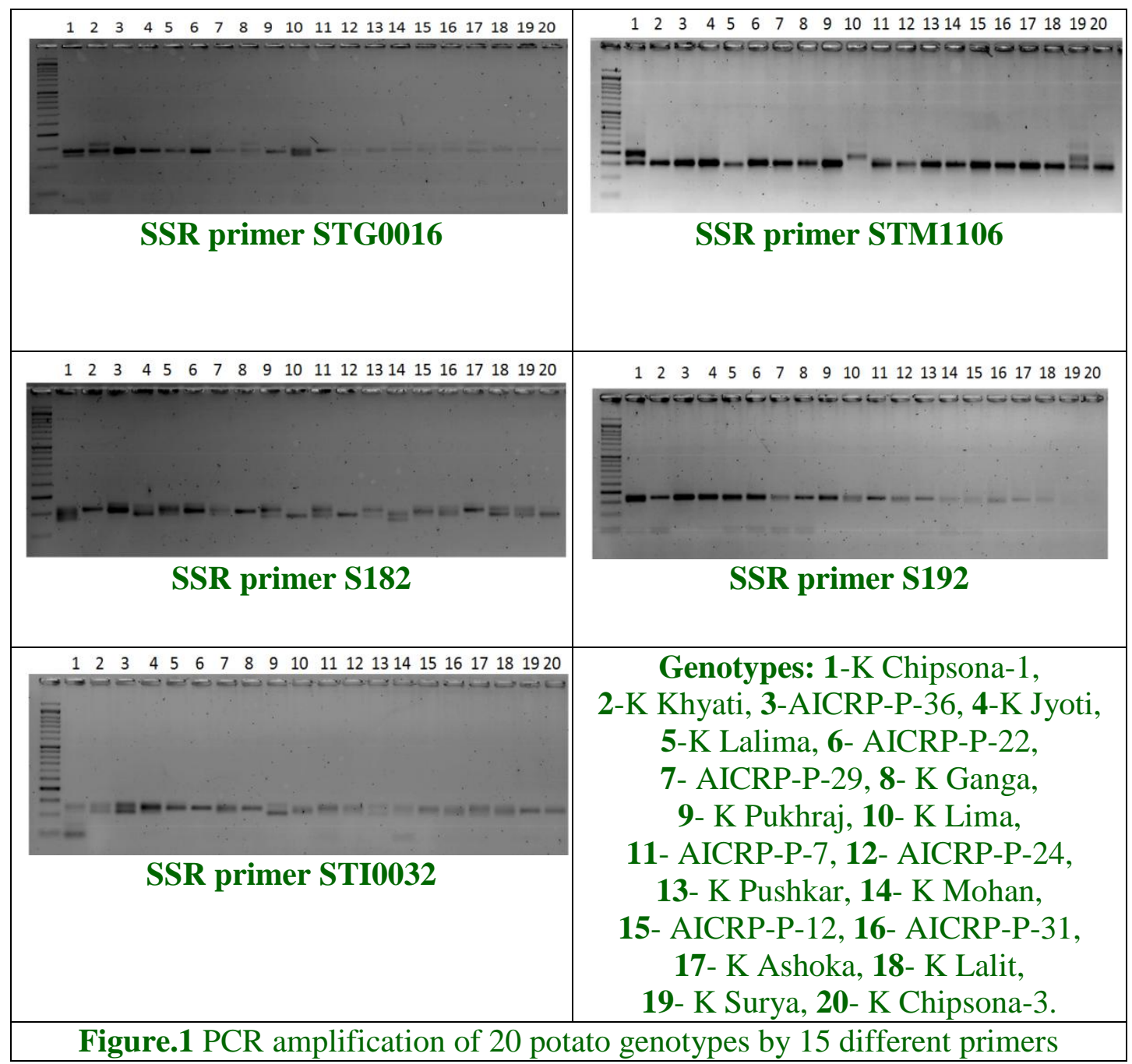


Fig.2 Dendrogram depicting the classification of the twenty genotypes of potato using UPGMA method based on SSR markers

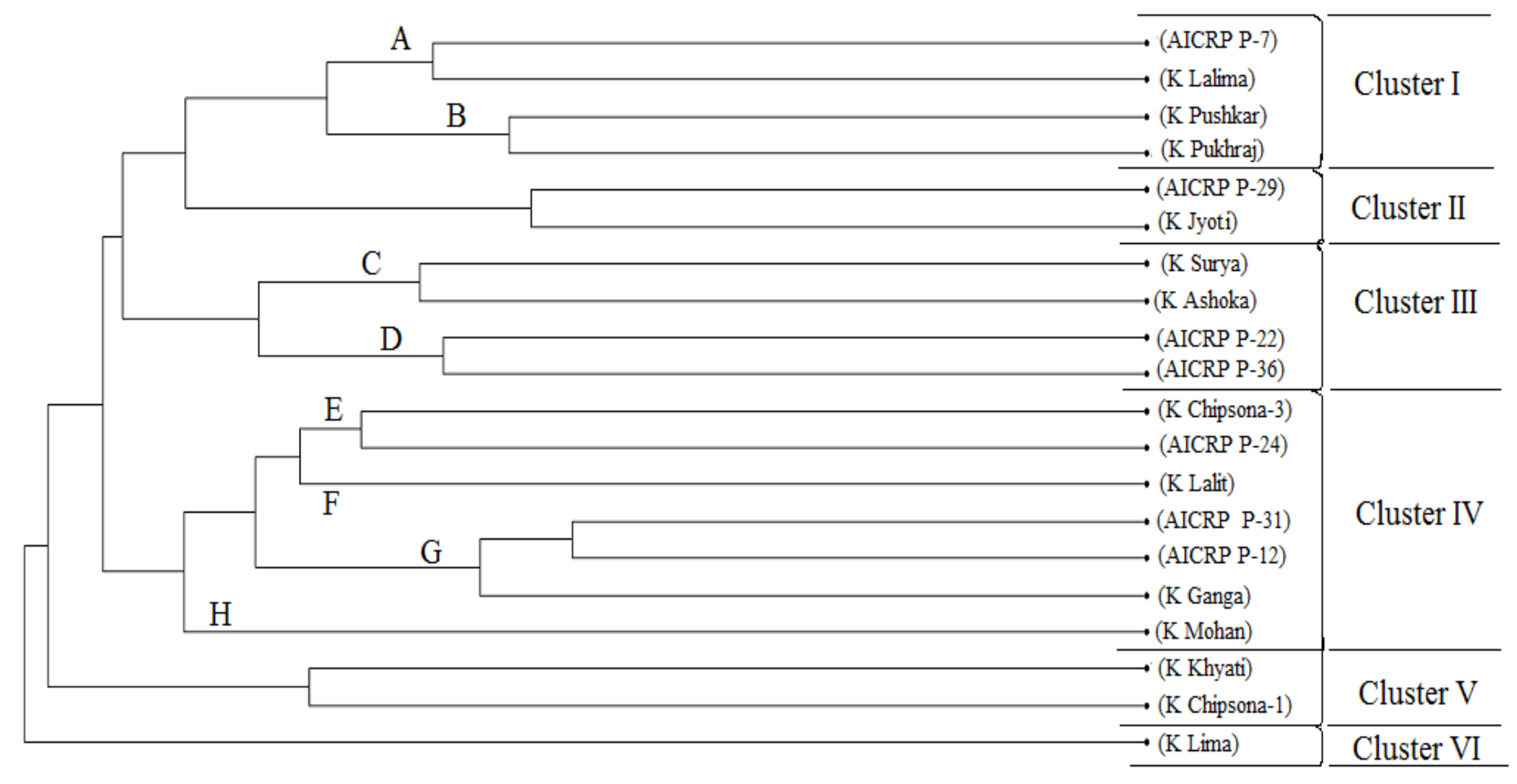


Barandalla and Galaretta (2006) constructed dendogram using Jaccard's similarity matrix. Out of fourteen polymorphic SSR primers, STM2005 was found to generate highest (four) amplified loci with all polymorphic bands. Similar results were reported by El Komy et al., (2012) who observed 93 percent primer polymorphism. Yanfeng Duan et al., (2019) detected 249 alleles using 20 markers and 244 of them (97.99\%) showed polymorphism.

The present study determined the pattern and level of genetic diversity among the selected 20 potato genotypes using 15 SSR markers. The microsatellites were useful and revealed considerable genetic variation among genotypes which can be exploited for possible crop improvement. The genotypes were clustered into six groups by means of 15 SSR markers. SSRs produced specific patterns, high polymorphism and placed genotypes in many clusters. This helped in differentiation among various genotypes under study. Therefore, use of SSR markers for the assessment of genetic diversity can help us to plan a better breeding program in future.

\section{References}

Barandalla L. and Galarette J.I.R. 2006. Molecular analysis of local potato cultivars from Tenerife Island using Micro satellite markers. Euphytica.152: 283.

Botstein D, White RL, Skolnick M and Davis RW. 1980. Construction of genetic linkage map in man using restriction fragment length polymorphisms. American journal of human genetics, 32(3): 314-331.

El Komy MH, Saleh AA and Molan YY. 2012. Molecular characterization of early blight disease resistant and susceptible potato cultivars using random amplified polymorphic DNA (RAPD) and simple sequence repeats
(SSR) markers. African Journal of Biotechnology, 11(1): 37-45.

Ghislain M, Andrade D, Rodríguez F, Hijmans RJ and Spooner DM. 2006. Genetic analysis of the cultivated potato Solanum tuberosum L. Phureja Group using RAPDs and nuclear SSRs, Theory of Applied Genetics, 113: $1515-1527$.

Gopal J. 2015. Challenges and way-forward in selection of superior parents, crosses and clones in potato breeding. Potato Research, 58, 165-188.

Govindaraj M, Vetriventhan $M$ and Srinivasan M. 2015. Importance of genetic diversity assessment in crop plants and its recent advances: An overview of its analytical perspectives. Genet Res International, 431-487.

Jaccard P. 1901. Etude de la distribution floraledansune portion des Alpeset du Jura. Bulletin del la Societe Vaudoise des Sciences Naturelles, 37: 547-579.

Jagesh KT, Nilofer A, Sapna D, Vinod K, Rasna Z and Swarup KC. 2018. Development of microsatellite markers set for identification of Indian potato varieties, Scientia Horticulturae, 231: 22-30.

Lachman J, Hamouz K, Orsak M and Pivec V. 2001. Potato glycoal kaloids and their significance in plant protection and nutrition, Rostlinna Vyroba, 47: 181-191.

Lisinska $G$ and Leszcynski W. 1989. Potato science and technology, Elsevier.

Mahmoud H, Amgad AS and Younes YM. 2012. Molecular characterization of early blight disease resistant and susceptible potato cultivars using random amplified polymorphic DNA (RAPD) and simple sequence repeats (SSR) markers, African Journal of Biotechnology, 11(1): 37-45.

Milbourne D, Meyer $\mathrm{R}$ and Bradshaw JE. 1997. Comparison of PCR-based 
marker systems for the analysis of genetic relationships in cultivated potato. Molecular Breeding, 3: 127.

Moisan-Thiery M, Marhadour S, Kerlan MC, Dessenne N, Perramant M, Gokelaere $\mathrm{T}$ and Hingrat YL. 2005. Potato cultivar identification using simple sequence repeats markers (SSR), Potato Research, 48: 191-200.

PPV \& FR Act. 2001. The protection of Plant Varieties and Farmer's Right Act (No. 53 of 2001). Department of Agriculture and Cooperation, Ministry of Agriculture, Government of India, Krishi Bhavan, New Delhi.

Prossy N, Julia S, Rob M and Alex B. 2017.Genetic characterisation and diversity assessment of potato genotypes using SSR markers, Journal of Agricultural Science, 9(8).

Rytel E, Golubowska G, Lisińska G, Pęksa A and Aniolowski K. 2005. Changes in glycoalkaloid and nitrate contents in potatoes during french fries processing, Journal of the Science of Food Agriculture, 85: 879-882.

Yanfeng D, Jie L, Jianfei X, Chunsong B, Shaoguang D, Wanfu P, Jun $H$, Guangcun L and Liping J. 2019. DNA fingerprinting and genetic diversity analysis with simple sequence repeat markers of 217 potato cultivars (Solanum tuberosum L.) in China. American Journal of Potato Research, 96: 21-32.

\section{How to cite this article:}

Singh, B. R. S. S., A. Mishra, M. K. Kar, R. P. Sah, M. Behera and Bal, A. 2020. Genetic Diversity Analysis of Table Potato Genotypes Using SSR Markers. Int.J.Curr.Microbiol.App.Sci. 9(08): 3198-3211. doi: https://doi.org/10.20546/ijcmas.2020.908.365 